\title{
Field Test of the Methodology for Succession Planning for Technical Experts
}

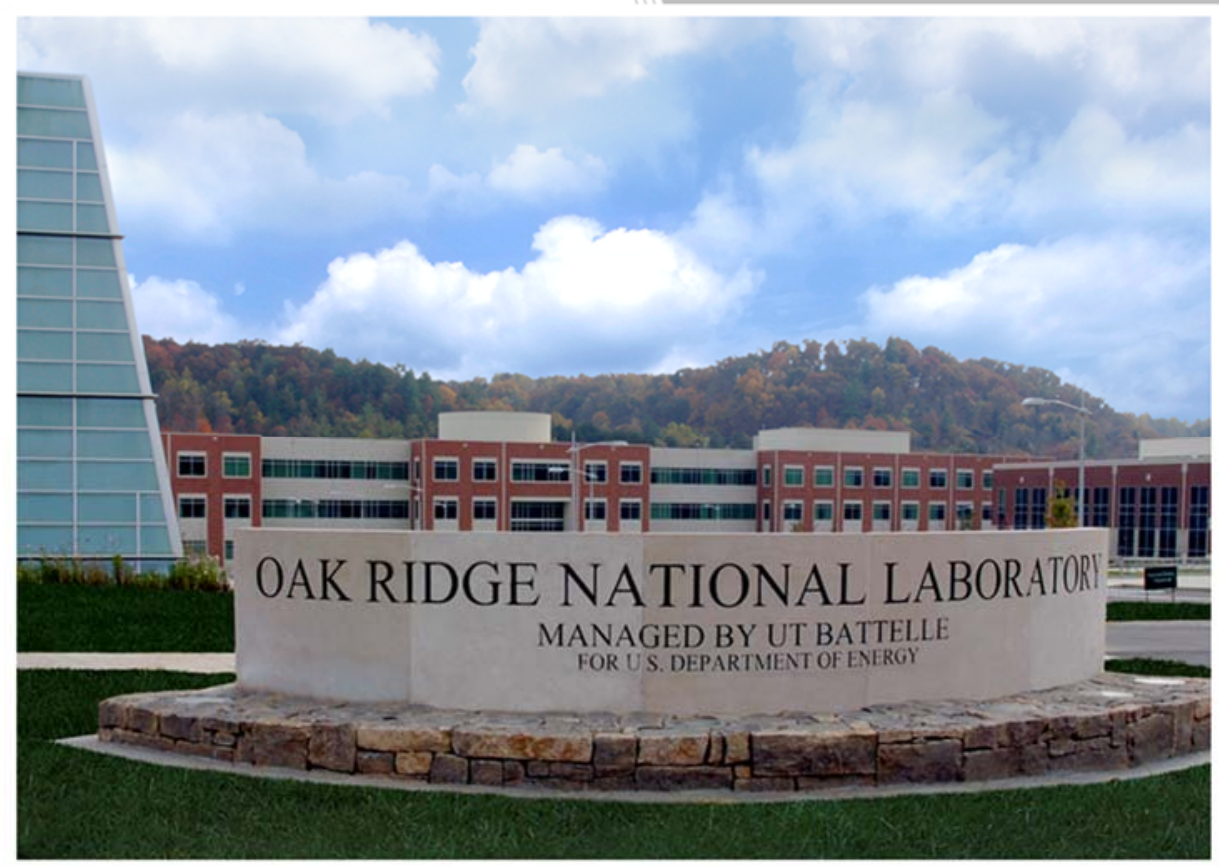

Approved for public release.

Ron Cain

Carla Agreda

Bernadette Kirk

Distribution is unlimited.

May 2018 


\title{
DOCUMENT AVAILABILITY
}

Reports produced after January 1, 1996, are generally available free via US Department of Energy (DOE) SciTech Connect.

Website http://www.osti.gov/scitech/

Reports produced before January 1, 1996, may be purchased by members of the public from the following source:

\author{
National Technical Information Service \\ 5285 Port Royal Road \\ Springfield, VA 22161 \\ Telephone 703-605-6000 (1-800-553-6847) \\ TDD 703-487-4639 \\ Fax 703-605-6900 \\ E-mailinfo@ntis.gov \\ Website http://classic.ntis.gov/
}

Reports are available to DOE employees, DOE contractors, Energy Technology Data Exchange representatives, and International Nuclear Information System representatives from the following source:

Office of Scientific and Technical Information

PO Box 62

Oak Ridge, TN 37831

Telephone 865-576-8401

Fax 865-576-5728

E-mail reports@osti.gov

Website http://www.osti.gov/contact.html

This report was prepared as an account of work sponsored by an agency of the United States Government. Neither the United States Government nor any agency thereof, nor any of their employees, makes any warranty, express or implied, or assumes any legal liability or responsibility for the accuracy, completeness, or usefulness of any information, apparatus, product, or process disclosed, or represents that its use would not infringe privately owned rights. Reference herein to any specific commercial product, process, or service by trade name, trademark, manufacturer, or otherwise, does not necessarily constitute or imply its endorsement, recommendation, or favoring by the United States Government or any agency thereof. The views and opinions of authors expressed herein do not necessarily state or reflect those of the United States Government or any agency thereof. 


\title{
FIELD TEST OF THE METHODOLOGY FOR SUCCESSION PLANNING FOR TECHNICAL EXPERTS
}

\author{
Ron Cain \\ Carla Agreda \\ Bernadette Kirk ${ }^{1}$
}

Date Published: May 2018

\author{
Prepared by \\ OAK RIDGE NATIONAL LABORATORY \\ Oak Ridge, TN 37831-6283 \\ Managed by \\ UT-BATTELLE, LLC \\ For the \\ US DEPARTMENT OF ENERGY \\ Under contract DE-AC05-00OR2272
}

\footnotetext{
${ }^{1}$ Kirk Nuclear Information Services
} 



\section{CONTENTS}

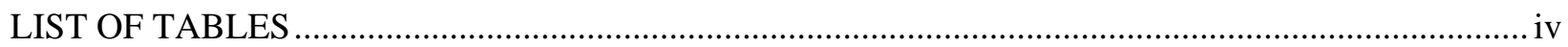

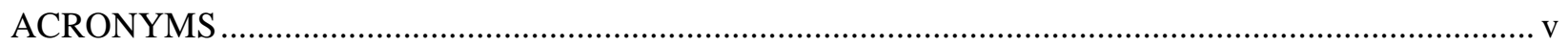

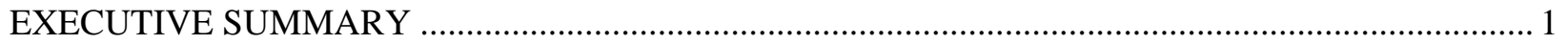

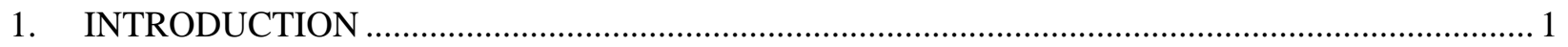

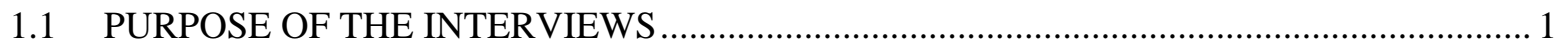

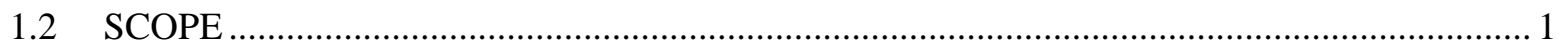

2. REVIEW OF CORE COMPETENCIES METHODOLOGY …........................................... 1

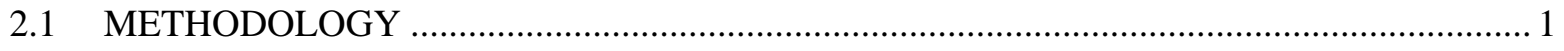

2.1.1 Select a Nuclear Facility or Group of Experts at a DOE National Laboratory ............... 2

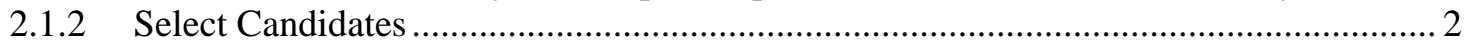

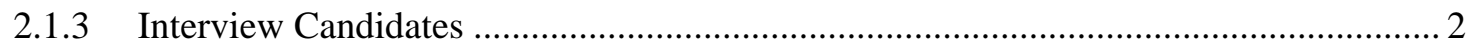

2.1.4 Analyze Interview Results ........................................................................... 2

2.1.5 Validate Core Competencies and Level of Criticality ................................................ 3

2.1.6 Assess Potentially Core Competencies .................................................................... 3

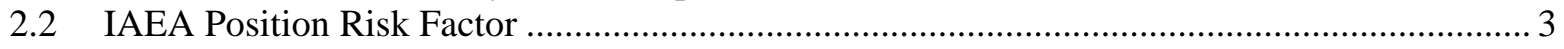

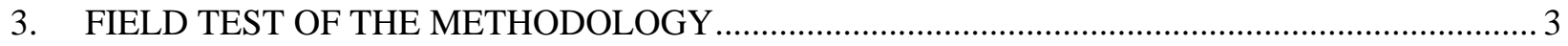

3.1 SELECTION OF NUCLEAR FACILITY AND CANDIDATES, INTERVIEW

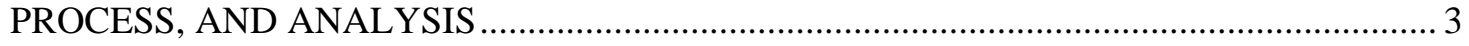

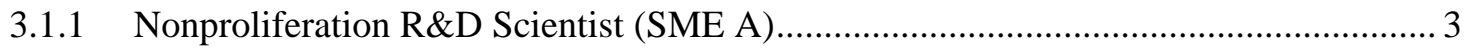

3.1.2 Safeguards R\&D Manager (SME B) ….................................................................. 5

3.1.3 Nonproliferation Technical Trainer (SME C) ....................................................... 7

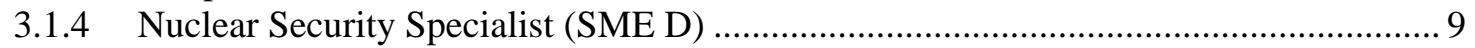

3.2 VALIDATION AND ASSESSMENT OF CORE COMPETENCIES ................................. 11

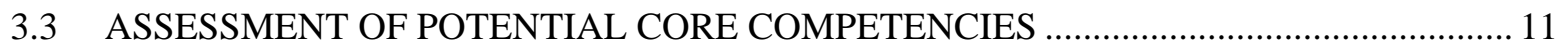

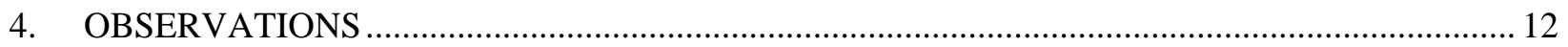

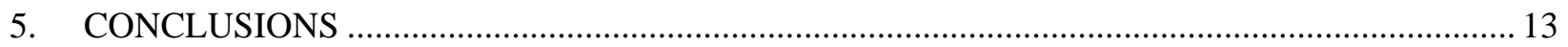

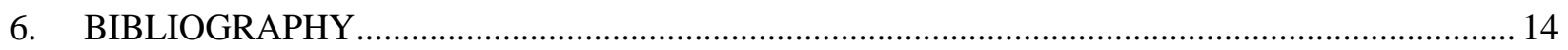

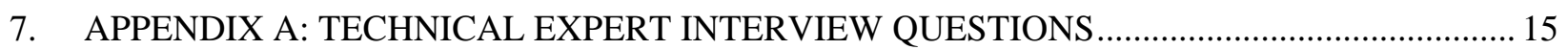




\section{LIST OF TABLES}

Table 1. Core competencies for nonproliferation R\&D scientist (SME A) …...................................... 5

Table 2. Core competencies for Safeguards R\&D Manager (SME B) …............................................ 7

Table 3. Core competencies for Nonproliferation Technical Trainer (SME C)...................................... 9

Table 4. Core competencies For Nuclear Security Specialist (SME D) ................................................ 11 


\section{ACRONYMS}

$\begin{array}{ll}\text { AIChE } & \text { American Institute of Chemical Engineers } \\ \text { AVLIS } & \text { Atomic Vapor Laser Isotope Separation } \\ \text { BS } & \text { bachelor of science } \\ \text { DOE } & \text { Department of Energy } \\ \text { HR } & \text { Human Resources } \\ \text { IAEA } & \text { International Atomic Energy Agency } \\ \text { INMM } & \text { Institute for Nuclear Materials Management } \\ \text { MINOS } & \text { Multi-informatics for Nuclear Operations Scenarios } \\ \text { MS } & \text { master of science } \\ \text { NN-20 } & \text { Office of Nonproliferation Research and Engineering } \\ \text { NNSA } & \text { National Nuclear Security Administration } \\ \text { NSITD } & \text { Nuclear Security and Isotope Technology Division } \\ \text { ORNL } & \text { Oak Ridge National Laboratory } \\ \text { PhD } & \text { doctor of philosophy } \\ \text { R\&D } & \text { research and development } \\ \text { RNSD } & \text { Reactor and Nuclear Systems Division } \\ \text { SME } & \text { subject matter expert } \\ \text { UVT } & \text { Uranium Verification Team } \\ \text { Y-12 } & \text { Y-12 National Security Complex }\end{array}$




\section{EXECUTIVE SUMMARY}

This report complements A Methodology for Succession Planning for Technical Experts (Ron Cain, Shaheen Dewji, Carla Agreda, Bernadette Kirk, July 2017), which describes a methodology for identifying and evaluating the loss of key technical skills at nuclear operations facilities. This report targets the methodology for identifying critical skills, hereafter referred to as "core competencies". The methodology has been field tested by interviewing selected retiring subject matter experts (SMEs).

\section{INTRODUCTION}

\subsection{PURPOSE OF THE INTERVIEWS}

A methodology to identify core competencies was suggested in a 2017 report (Ron Cain, Shaheen Dewji, Carla Agreda, Bernadette Kirk, July 2017). In an ensuing report (Ron Cain, Carla Agreda, Bernadette Kirk, August 2017), the methodology was piloted through personal interviews of SMEs identified as key personnel by his or her management. The purpose of the interviews was to identify core competencies of SMEs and rank each according to a position risk factor. The ranking analysis then enables an institution to implement a succession plan based on the potential loss of SMEs.

In August 2017, as part of a cost reduction initiative, Oak Ridge National Laboratory (ORNL) announced a voluntary reduction in force program for eligible ORNL staff. ORNL project members saw this as an opportunity to field test the draft methodology and received permission from the Department of Energy/National Nuclear Security Administration (DOE/NNSA) program manager to extend the project. Specifically, staff members accepted for the reduction were notified on October 25, 2017, and were required to leave the payroll by December 31, 2017. With the assistance of the ORNL Human Resources (HR) group, interviews with selected experts were conducted to determine, analyze, and rank critical competencies. Experience gained in the interviews will be used to either refine the current interview question set or develop parallel discipline-specific sets that improve the quality of results gained. This report summarizes results of the ORNL voluntary reduction in force field test.

\subsection{SCOPE}

Interviews focused on retiring SMEs with relevant nuclear nonproliferation or safeguards expertise. Section 2 reviews the core competencies methodology and the International Atomic Energy Agency (IAEA) position risk factor. Section 3 covers the respective interviews of SMEs. Section 4 relates to lessons learned.

\section{REVIEW OF CORE COMPETENCIES METHODOLOGY}

\subsection{METHODOLOGY}

A six-step methodology for identifying core competencies has been developed. The following methodology is taken from an earlier report in this series (Ron Cain, Shaheen Dewji, Carla Agreda, Bernadette Kirk, July 2017):

1. Select a nuclear facility or identify a group of experts at a DOE national laboratory

2. Select candidates

3. Interview candidates

4. Analyze interview results

5. Validate core competencies and level of criticality 
6. Assess potential core competencies

Each of the steps above will be described, in order, in the following subsections.

\subsubsection{Select a Nuclear Facility or Group of Experts at a DOE National Laboratory}

The selected facility must be integral to DOE's mission and have been in operation for several years. Because they support DOE's mission, experts must have worked in the facility or group for a considerable amount of time.

\subsubsection{Select Candidates}

The manager of the facility or group aids in identifying individuals who have the desired core competencies needed to perform their jobs. Criteria can include how loss of the employee would impact on the organization; the minimum number of employees required for operation; employee job titles and job positions; and the number of employees eligible to retire. Individuals and job positions vital to laboratory operations are preferred candidates.

Specifically, the following steps are taken to identify appropriate candidates:

- Meet with facility or group manager and operations managers to identify individuals with core competencies in their respective areas.

- Interview operations managers to determine the individual(s) whose departure(s) would negatively impact the organization. Obtain the job titles and job descriptions for these individuals. If many individuals are identified and a job title is shared by more than one individual, ask the manager to categorize the job importance of those individuals based on the impact of losing him or her on short notice.

- Validate the names of those deemed most critical by reviewing the skills list with the manager.

\subsubsection{Interview Candidates}

The interview process involves a prepared questionnaire (see Appendix A) and at least two interviewers - one asking questions and the other recording the session and possibly employing a recording device. One of the interviewers should have technical know-how or familiarity with the expert's field. The questionnaire will be reviewed by the manager and then sent to the potential interviewee/expert prior to the session. The interviewee is informed by their manager of the purpose of the interview and its importance. The potential interviewee/expert completes the form and returns it to the interviewers. Once the interviewers receive a copy of the completed questionnaire and have had a chance to evaluate the input, a date is set for the follow-up face-to-face session. The follow-up interview should occur in a quiet place. After the interview session is over, the interviewers provide a summary of the interview to the interviewee. The summary should be vetted by the SME to ensure that no errors were made in the transcription.

\subsubsection{Analyze Interview Results}

The analysis is designed to determine potential core competencies. The interviewers take the notes from the interview and analyze the information to extract core competencies for each interviewee. The interviewers, with the aid of the facility manager, then review the questionnaires and interview transcripts to prepare a list of skills. A table of core competencies can then be compiled for each interviewee. 


\subsubsection{Validate Core Competencies and Level of Criticality}

Validating core competencies and their level of criticality is performed by the manager, the interviewers, and preferably a resident expert who is familiar with the interviewee's functions. The manager ensures the core competencies are aligned with the organization's mission. The interviewers share their analysis with the manager and/or operations managers to validate the criticality of the skills identified and to ascertain the level of criticality of each skill and individual. The relevant job descriptions for the interviewees also play a crucial role in validating core competencies. The agreed-upon level of criticality is included in the analysis as a spreadsheet.

\subsubsection{Assess Potentially Core Competencies}

As a final output, the assessment features a table of skills with a level of criticality defined for each skill. The interviewers complete the table with results from the interviews and provide the output to the facility or group manager and the operations managers who can then proceed to plan for knowledge retention for key core competencies.

\subsection{IAEA POSITION RISK FACTOR}

The output from each interview, together with the job description, is summarized in a table with the core competencies listed first. Each skill is ranked from 1 to 5, using the IAEA's position risk factor criteria (IAEA, 2006). A version of the IAEA ranking follows.

5-Most critical, no replacement readily available, lack of documentation for tacit knowledge

4-Critical, few available replacements, some documentation of tacit knowledge

3-Critical, replacements available, documentation of tacit knowledge exists

2-Not mission critical, recruits trainable in a year

1-Least critical, replacement through external hires

The above version of the IAEA ranking is used in the next section to identify core competencies. For clarity, tacit knowledge resides in individuals and is difficult to document (IAEA Nuclear Energy Series, 2011).

\section{FIELD TEST OF THE METHODOLOGY}

\subsection{SELECTION OF NUCLEAR FACILITY AND CANDIDATES, INTERVIEW PROCESS, AND ANALYSIS}

With the help of the human resources (HR) personnel at ORNL, four retiring SMEs were identified for interviews: a nonproliferation research and development (R\&D) scientist, a safeguards R\&D manager, a nonproliferation technical trainer, and a nuclear security specialist.

\subsubsection{Nonproliferation R\&D Scientist (SME A)}

The first interviewee will be referred to as "SME A.” SME A is a distinguished research and development (R\&D) scientist with a bachelor of science (BS), master of science (MS), doctor of philosophy (PhD) in nuclear engineering from the University of Tennessee. He has 36 years of experience as staff member and prior to that, 4 years as student intern. 
SME A's expertise lies in nuclear criticality safety, radiation protection, reactor physics, source term modeling, nuclear security, and computer code development. All of his experience was at ORNL, where he worked as a graduate student prior to employment.

SME A worked in the Reactor and Nuclear Systems Division (RNSD). As a staff scientist in RNSD, he applied his skills in reactor physics, radiation protection, and criticality safety. He later joined a nuclear security group and performed work for the NNSA, in particular the Office of Defense Nonproliferation Research and Development (NA-22). He was a principal investigator for NA-22 projects primarily focused on reactor physics. Specific projects in reactor physics included production reactors and their effluents. He developed computer models for the reactors and the types of effluents from the reactors. Because of his experience in NA-22 projects, he accepted a 2 year assignment in Washington, DC, working for that office.

After his assignment in DC, he returned to ORNL and became involved in project management. He initially managed the project Multi-Informatics for Nuclear Operations Scenarios (MINOS) to develop a testbed around the High Flux Isotope Reactor and the Radiochemical Engineering Development Center, and he led the project for 1 year. MINOS is expected to be a 5-10 year project.

When asked to identify areas that fellow employees seek his expertise, SME A's response was radiation transport, reactor modeling, sensitivity and uncertainty analysis, packaging for radioactive material transport and storage, source term generation, and nuclear forensics. The primary sponsors for packaging activities were the Nuclear Regulatory Commission and the NNSA Y-12 National Security Complex (Y12), and his primary forensics sponsors were Department of Homeland Security and NA-22.

Targeted recruitment is the main mechanism used by the groups he worked in to capture the knowledge of experts before they left ORNL. Many of the recruits are either new graduates or experienced staff. Emphasis is placed on mentoring, particularly for postdoctoral associates and new staff. A strategic planning meeting where his group leader meets with his distinguished R\&D staff members to evaluate the research areas and assess staffing needs is held monthly.

Organizational resources include a variety of technical training. When he returned from his DC assignment, he participated in ORNL’s Management Boot Camp. Early in his career, he took computational training, which complemented his expertise in code development. As a computer code expert, he became a trainer himself. In this position, there was no need to attend job-specific training.

SME A had to keep current with open literature publications, particularly for code and methodology development. Much of the development work, particularly in forensics and sensitivity/uncertainty analysis, required information about what had been done before.

In addition to his primary role of project management, SME A continued to pursue R\&D. In the strategic planning team for his group, he served as a mentor for a new staff member.

SME A believed that with his retirement, a replacement would take 1-2 years to adequately assume the role. The replacement would need about 6 months to train.

The top three things SME A would share with someone new to his role are: (1) to stay current on technology, (2) to learn the sponsor's needs, and (3) to surround oneself with a good diverse team.

SME A recommends that staff assuming his position would need strong communication skills (both oral and written) and leadership skills. 
The availability of resources is important in his work. This includes the Radiation Safety Information Computational Center and documentation as provided by the SCALE project (A comprehensive modeling and simulation suite for nuclear safety analysis and design). The Spent Fuel Isotopic Composition database, a relational database designed to facilitate the search and visualization of experimental assay data of spent nuclear fuel, developed by the Nuclear Energy Agency in collaboration with ORNL, is also a key resource in his work.

SME A participated in an ongoing NA-22 project called SIGNPOST, which aims to capture information about NA-22's past projects. SIGNPOST will document the research carried out under NA-22 for past 15 years. A one-page summary for every project (about 1,000 total) will be written and placed into a database to be shared, and a wiki page that links to the one page summaries will be created.

SME A was a past member of the American Nuclear Society.

Table 1 depicts the core competencies extracted from SME A's interview. Verification of the ranking was done by SME A.

Table 1. Core competencies for Nonproliferation R\&D Scientist (SME A)

\begin{tabular}{|c|c|c|c|c|c|}
\hline Core Competencies for Nonproliferation SME - R\&D Scientist & 1 & 2 & 3 & 4 & 5 \\
\hline $\begin{array}{l}\text { Performs independently in specialty area (radiation transport, reactor modelling, } \\
\text { sensitivity and uncertainty analysis, packaging of radioative materials) and actively } \\
\text { imparts knowledge to others }\end{array}$ & & & & & $\checkmark$ \\
\hline Plans and coordinates programs and large-scale projects & & & & & $\checkmark$ \\
\hline Ability to interact with international experts and the IAEA staff & & & & & $\checkmark$ \\
\hline Understanding radiation transport & & & & & $\checkmark$ \\
\hline Understanding reactor physics & & & & & $\checkmark$ \\
\hline Understanding sensitivity and uncertainty analysis & & & & & $\checkmark$ \\
\hline Understanding nuclear criticality safety & & & & & $\checkmark$ \\
\hline Understanding the packaging of nuclear materials & & & & & $\checkmark$ \\
\hline Ability to write research papers and presentations & & & & & $\checkmark$ \\
\hline Availability to attend required training and certification & & & & $\checkmark$ & \\
\hline Ability to interface with funding agency & & & & & $\checkmark$ \\
\hline Ability to interface with other national laboratories & & & & $\checkmark$ & \\
\hline Ability to communicate with other staff & & & & & $\checkmark$ \\
\hline Ability to accept criticism & & & & $\checkmark$ & \\
\hline Ability to face a difficult situation (conflict resolution) & & & & & $\checkmark$ \\
\hline Ability to face constant time pressure & & & & & $\checkmark$ \\
\hline Critical thinking & & & & & $\checkmark$ \\
\hline Complex problem solving & & & & & $\checkmark$ \\
\hline Judgment and decision making & & & & & $\checkmark$ \\
\hline Active listening & & & & $\checkmark$ & \\
\hline Performs independent reviews, studies and analyses in of technical projects & & & & $\checkmark$ & \\
\hline
\end{tabular}

\subsubsection{Safeguards R\&D Manager (SME B)}

SME B was a group leader in the Nuclear Security and Isotope Technology Division (NSITD) before retiring. He was also the ORNL customer interface manager for the DOE/NNSA Office of Nonproliferation and Arms Control (NA-24). He has BS, MS, and PhD degrees in chemical engineering. He came to ORNL in May 1974 and worked at ORNL for 43 years. SME B's expertise is in the nuclear fuel cycle, particularly uranium conversion, enrichment, and fuel fabrication. 
SME B was in the Chemical Technology Division from May 1974 to November 1987 and from July 1989 to September 2001. Between these two periods, he joined the Atomic Vapor Laser Isotope Separation (AVLIS) program from December 1987 to June 1989. He returned to the Chemical Technology Division in July 1989 as a section head.

In the late 1970s, SME B studied parts of the nuclear fuel cycle, starting with the production of uranium oxide $\left(\mathrm{UO}_{2}\right)$ fuel spheres, separation of zirconium and hafnium to produce nuclear-grade zirconium, wastewater treatment to capture the fission products strontium $\left({ }^{90} \mathrm{Sr}\right)$ and cesium $\left({ }^{134} \mathrm{Cs} /{ }^{137} \mathrm{Cs}\right)$, uranium enrichment by the AVLIS process, production of uranium metal as feed for AVLIS, and purification of enriched uranium and conversion to uranium hexafluoride $\left(\mathrm{UF}_{6}\right)$. Since 2003 , he had been involved in nuclear safeguards for uranium and plutonium.

Prior to retiring, SME B was a group leader for the ORNL Nonproliferation Technology section. He was also the co-lead of the DOE/NNSA Office of Nuclear Verification-sponsored Uranium Verification Team (UVT), which consists of experts from Idaho National Laboratory, Los Alamos National Laboratory, Lawrence Livermore National Laboratory, ORNL, Pacific Northwest National Laboratory, Savannah River National Laboratory, and Y-12.

SME B visited North Korea twice (2008) as part of the six-party talks that included the International Atomic Energy Agency (IAEA) and the US. He participated in the assessment to determine if North Korea was defueling its reactor. That work led to the UVT, which was formed in 2015.

SME B has ten staff members in his group who are considered early career and are being trained to continue the UVT work. Their training includes virtual reality and facility visits. The training also focuses on centrifuges, fuel conversion, and reprocessing.

SME B viewed this interview as part of the knowledge capture process. The setup of the UVT can also be considered as knowledge preservation according to him.

Organizational resources for SME B's job include ORNL's implementation of “Systems, Applications and Products (SAP) “, the project management support staff and the technical staff.

Before he assumed a management role, SME B kept current with open literature publications in American Institute of Chemical Engineers (AIChE) journals, the Nuclear Review, Chemical Engineering Science, and other chemical engineering journals.

SME B is not required to attend job-specific critical training on a regular basis. He is responsible for determining the training conducted yearly by the UVT, which stresses the front end of the nuclear fuel cycle.

In addition to being a group leader, SME B had several additional roles in the division including document classification officer, report highlights coordinator, lead for the ORNL Building 5300N third floor Limited Area and several vault type rooms, final division document reviewer, chair of the NSITD Software Quality Assurance Review Board, and NSITD Facilities Operations Manager for Building 5300.

With his retirement from ORNL effective December 31, 2017, SME B's responsibilities are being reassigned to a number of current staff. The timeframe for training his replacements will be just a few days or weeks because these staff members are generally knowledgeable. 
The most important three things SME B would share with someone new to his role are (1) to network with others and listen, (2) become as knowledgeable as possible about the nuclear fuel cycle, and (3) study soft skills such as how to deal with others.

For documented resources, SME B mentioned that reports have been kept electronically. The UVT has a SharePoint site, which is available to the entire DOE/NNSA complex. The IAEA databases on nuclear facilities are also useful.

SME B is a member of AIChE, the American Nuclear Society local section, Tau Beta Pi, and the Institute for Nuclear Materials Management (INMM). Earlier in his career, he was very active in AIChE. He decided that the INMM meetings were more relevant to his line of work and has attended many meetings since 2003.

Based on the interview alone, Table 2 depicts the core competencies for SME B with feedback from him.

Table 2. Core competencies for Safeguards R\&D Manager (SME B)

\begin{tabular}{|c|c|c|c|c|c|}
\hline Core Competencies for Safeguards R\&D Manager & 1 & 2 & 3 & 4 & 5 \\
\hline $\begin{array}{l}\text { Performs independently in specialty area (nuclear fuel cycle, particularly uranium } \\
\text { conversion, enrichment, and fuel fabrication ) and actively imparts knowledge to } \\
\text { others }\end{array}$ & & & & & $\checkmark$ \\
\hline $\begin{array}{l}\text { Knowledge of IAEA safeguards and their implementation with a focus on enrichment } \\
\text { activities }\end{array}$ & & & & & $\checkmark$ \\
\hline Plans and coordinates programs and large-scale projects & & & & & $\checkmark$ \\
\hline Ability to interact with international experts and the IAEA staff & & & & & $\checkmark$ \\
\hline Understanding the nuclear fuel cycle & & & & & $\checkmark$ \\
\hline Understanding centrifuge technology & & & & & $\checkmark$ \\
\hline Understanding material movement procedures and hardware & & & & & $\checkmark$ \\
\hline Understanding material accountability requirements and practices & & & & & $\checkmark$ \\
\hline Understanding conversion for uranium and plutonium & & & & & $\checkmark$ \\
\hline Availability to attend required training and certification & & & & $\checkmark$ & \\
\hline Ability to interface with funding agency & & & & & $\checkmark$ \\
\hline Ability to interface with other national laboratories & & & & & $\checkmark$ \\
\hline Ability to communicate with other staff & & & & & $\checkmark$ \\
\hline Ability to accept criticism & & & & $\checkmark$ & \\
\hline Ability to face a difficult situation (conflict resolution) & & & & & $\checkmark$ \\
\hline Ability to face constant time pressure & & & & & $\checkmark$ \\
\hline Critical thinking & & & & & $\checkmark$ \\
\hline Complex problem solving (fuel cycle) & & & & & $\checkmark$ \\
\hline Judgment and decision making (fuel cycle) & & & & & $\checkmark$ \\
\hline Active listening & & & & $\checkmark$ & \\
\hline Performs independent reviews, studies and analyses in of technical projects & & & & $\checkmark$ & \\
\hline
\end{tabular}

\subsubsection{Nonproliferation Technical Trainer (SME C)}

SME C was a trainer for selected aspects of export controls and nonproliferation for 15 years prior to retirement. He holds a chemical engineering $\mathrm{PhD}$ from the University of Pennsylvania. Soon after he obtained his $\mathrm{PhD}$, he started work as a professor at the University of Rochester and held that position for about 6 years before coming to ORNL as a researcher in 1980. 
SME C worked at ORNL for 37 years. He began as a researcher in the Chemical Technology Division and was involved in research in chemical engineering for 15 years. He then moved to work on nonproliferation projects. From 1998 to 1999, he was assigned to work in Washington, DC, in the former DOE/NNSA Office of Nonproliferation Research and Engineering (NN-20). When he returned to ORNL, he became involved in export control programs. He gained expertise in that area and soon became a trainer. His strong scientific background helped in the role as a trainer.

Prior to retirement, his job was to train people in the DOE complex about aspects of export control. He mainly developed materials and delivered training in a workshop environment, which was mostly international, and in some cases, domestic. For each workshop, he taught from 2 to 4 days. The sponsoring organization was the Office of Nuclear Export Controls (NA-242) International Nonproliferation Export Control Program, which addresses four kinds of weapons of mass destructionchemical, nuclear, biological, and missile delivery. He was assigned nonproliferation of chemical weapons because of his chemical expertise. He was responsible for organizing and leading training events in Kenya and South Africa. In addition, he used to be the SME for training teams for other countries.

Unique skills required in his assignment as a trainer include a background in chemistry. He believes that it is important to know how to communicate in a training environment, how to develop training materials, how to deliver training. It is also important to be aware of the need to evaluate effectiveness. Feedback from trainees is also important. Training topics included the components needed to make nuclear and chemical weapons, including which are specialized and which have dual uses. These items are monitored with respect to shipping locations, so nontechnical personnel were also trained to watch for them.

Available resources that aid in his job include the internet for accessing published research. SME C also worked with colleagues with similar technical backgrounds at other national laboratories. Colleagues at other federal agencies helped with his work. Some of the agencies include the Department of Commerce, Department of Homeland Security, Customs and Border Protection, and the Department of State.

To some extent, SME C stays current with open literature publications. In his job, subscribing to news alerts was important because he needed to be aware of is what is occurring throughout the world and existing situations in the country where training will be held.

SME C was not required to attend job-specific critical training on a regular basis, and he also had opportunities to attend a variety of specialized training.

Other roles he played at ORNL included mentoring to help develop new staff. He did quite a bit of informal mentoring, and he was told that he was good at providing constructive criticism.

With SME C's retirement, a replacement who has not had any experience in the job could take 1 year to develop a basic competency. SME C had been working with a staff member to take over his job for at least 1 year.

SME C offered the following three pieces of advice to a hypothetical new staff member assuming his role:

1. understand your audience so you can speak to what they need to know. Learn how to communicate with nontechnical people.

2. Training is a relationship environment, so learn how to handle yourself professionally and personally in a different culture. Let your clients know you are happy to be in their country and try to learn from them.

3. Training is not just about technical knowledge. 
To capture vital knowledge, training materials for the program are all maintained in a document management system called eRoom. eRoom also stores databases.

SME C viewed membership in a professional society as unimportant to his job performance and day-today responsibilities. Based on the interview alone, Table 3 depicts the core competencies for SME C, with feedback from him.

Table 3. Core competencies for Nonproliferation Technical Trainer (SME C)

\begin{tabular}{|c|c|c|c|c|}
\hline Core Competencies for Nonproliferation Technical Trainer & 1 & 3 & 4 & 5 \\
\hline $\begin{array}{l}\text { Performs independently in specialty area (nonproliferation - export control) and } \\
\text { actively imparts knowledge to others }\end{array}$ & & & & $\checkmark$ \\
\hline Plans workshops and development of training materials for export control & & & & $\checkmark$ \\
\hline Ability to interact with the international experts & & & & $\checkmark$ \\
\hline Ability to communicate scientific concepts to a non-technical audience & & & & $\checkmark$ \\
\hline Understanding the chemistry of weapons of mass destruction (WMD) & & & $\checkmark$ & \\
\hline Understanding what components are needed to make nuclear and chemical weapons & & & $\checkmark$ & \\
\hline Understanding export control of WMD parts and materials & & & & $\checkmark$ \\
\hline Availability to attend required training and certification & & $\checkmark$ & & \\
\hline Ability to interface with funding agencies & & & $\checkmark$ & \\
\hline Ability to interface with other national laboratories & & & $\checkmark$ & \\
\hline Ability to communicate with other staff & & & $\checkmark$ & \\
\hline Ability to accept criticism & & & $\checkmark$ & \\
\hline Ability to face a difficult situation (conflict resolution) & & & $\checkmark$ & \\
\hline Ability to face constant time pressure & & & $\checkmark$ & \\
\hline Critical thinking & & & $\checkmark$ & \\
\hline Complex problem solving (export control) & & & & $\checkmark$ \\
\hline Judgment and decision making (export control) & & & & $\checkmark$ \\
\hline Active listening & & & $\checkmark$ & \\
\hline $\begin{array}{l}\text { Performs independent reviews, studies and analyses in of technical projects in } \\
\text { export control }\end{array}$ & & & & $\checkmark$ \\
\hline
\end{tabular}

\subsubsection{Nuclear Security Specialist (SME D)}

SME D was a material protection, control, and accounting specialist. He holds a BS degree in science and education from Ohio University, an associates degree in law enforcement and safety and security, and has completed some graduate work. He worked as a consultant with ORNL for about 1 year before he was hired as an employee. He was at ORNL for 14 years.

He completed a variety of training related to his job:

- Vulnerability assessment training at the National Training Academy

- Tactical response team training at the National Training Academy

- Crisis negotiations

- Crisis management

- Hostage negotiation

- Classification officer training at DOE (1 week course)

- Physical protection

SME D had experience as a nuclear security expert in previous jobs. He worked at the DOE/NNSA site in Portsmouth, Ohio, for 23 years, which is where he completed most of his training, including guard, 
security manager, tactical team commander, corporate classification officer (overseeing all the derivative classification officers at Oak Ridge, Portsmouth, and Paducah, Kentucky), and operations security (OPSEC) officer training.

Prior to retirement, SME D's major function was as a physical protection specialist. He evaluated security systems, identified deficiencies, conducted vulnerability assessments, wrote site reports, and planned for upgrades. He conducted training in Jordan and Nigeria.

SME D’s position required the following unique skill set:

- Knowledge of configuration of domestic and international security systems (i.e., what goes where and what works under what conditions)

- Knowledge of impacts of failure of components

- Knowledge of levels of maintenance required

- Knowledge of performance testing

- Country knowledge, particularly Russia and Kazakhstan

To capture vital knowledge, SME D documented his work for DOE. When a project was closed out, important files were packed and sent to the Office of Scientific and Technical Information.

SME D considers the ability to discuss work with his colleagues as an important organizational resource. The discussions are helpful because these colleagues have done parallel work, and their experiences can be shared.

Staying current on publications is not required in his job, but it is a survival requirement. SME D kept current with publications by the IAEA, World Institute for Nuclear Security, and Institute of Nuclear Material Management. He also searched the internet for on region, company, or country to find information relevant to the project on hand.

Other than the regular required training at ORNL, SME D did not have to take other classes. The only formal training he has had since coming to ORNL was the nonproliferation intelligence class.

Other roles SME D assumed were as derivative classifier, vulnerability assessor and integrator of the work of the protection force teams and the Material Protection Control and Accountability team with respect to physical protection.

Upon his retirement, a replacement with his background could transition into the job in 6 months. An individual newly out of college would take years to transition effectively. Experience is highly necessary because a college education is not preparation for this job. The best preparation would have been for SME D to directly train the person.

The top three things he would share with someone new to this role are: to be quiet and listen - get the lay of the land before you act; to look at what has been done before and why; and to talk to people who have been there and done that type of work.

For documented resources, Office of Scientific and Technical Information keeps project-specific records. An initial effort to prepare a database for his group is underway.

SME D is a member of INMM and was chair of the Physical Protection Division. He is also a member of the World Institute for Nuclear Security. Based on the interview alone, Table 4 depicts the core competencies for SME D with feedback from him. 
Table 4. Core competencies For Nuclear Security Specialist (SME D)

Core Competencies for Nuclear Security Specialist

Performs independently in specialty area (Nuclear Security - Material Protection,

Control and Accounting ) and actively imparts knowledge to others

Plans and coordinates physical protection of nuclear materials

Ability to interact with international experts and the IAEA staff

Understanding the concept of derivative classification

Understanding nuclear material protection, control and accounting

Understanding vulnerability assessment

Understanding material movement procedures and hardware

Understanding material accountability requirements and practices

Understanding uranium and plutonium storage as it relates to physical protection

Availability to attend required training and certification

Ability to interface with funding agency

Ability to interface with other national laboratories

Ability to communicate with other staff

Ability to accept criticism

Ability to face a difficult situation (conflict resolution)

Ability to face constant time pressure

Critical thinking

Complex problem solving (nuclear security)

Judgment and decision making (nuclear security)

Active listening

Performs independent reviews, studies and analyses in of technical projects

$\begin{array}{lllll}1 & 2 & 3 & 4 & 5\end{array}$

\subsection{VALIDATION AND ASSESSMENT OF CORE COMPETENCIES}

The interviewers initially prepared tables of core competency sets based on the responses of interviewees and preranked them (As described in step 2.1.5 of ORNL/TM-2017/424, Supplement to a Methodology for Succession Planning for Technical Experts). The tables were then sent to the interviewees to ensure that no core competency set was omitted and that each ranking reflected the value of the core competency. The rankings as drawn up by the interviewers were fairly close to the input from the interviewees.

\subsection{ASSESSMENT OF POTENTIAL CORE COMPETENCIES}

Because the interviews were conducted a few weeks before they retired, only the interviewees were able to review their respective ranking tables. 


\section{OBSERVATIONS}

The approach to field testing the methodology was to choose staff who retired from ORNL in December 2017. The interview questions were sent to the interviewees at least 2 weeks before the session to allow them sufficient time to prepare. This was very helpful as most of the interviewees had jotted notes in the questionnaire allowing for an efficient session. Each interview lasted about 1 hour. One of the interviewees answered the questions before the interview and provided the feedback to the interviewers before the session, which is highly desirable. Overall, the interviewees were all very eager and enthusiastic about sharing their experiences. This made it possible to ask questions that aided in setting up the core competency tables and corresponding rankings.

All interviews were conducted in a small conference room. The privacy and quietness afforded in this environment are ideal. During the interview sessions, one of the interviewers noted responses on a laptop computer. The responses were then merged with the feedback as received from the interviewees. The revised questionnaires that contained the original responses and the notes from the session together with the ranking table of core competencies were sent back to the interviewees for final comments.

A representative from HR adds substantial value to executing the methodology. Also, including one interviewer with technical knowledge related to the interviewees' skills sets is desirable. 


\section{CONCLUSIONS}

The identification of core competencies plays an important role in succession planning. An initial methodology to identify such skills was presented in a previous report by the authors (Ron Cain, Shaheen Dewji, Carla Agreda, Bernadette Kirk, July 2017). The authors took this initial methodology and performed a field test to demonstrate its utility through interviews of retiring staff.

To field test the methodology, interviews with four technical experts were conducted. Each interview led to a core competency analysis based on the questions asked. A table of core competencies was developed by the interviewers for each SME using the answers to the interview questions. In all four cases, the tables were verified and modified accordingly by the interviewees.

Future plans will include further field testing and working closely with HR to see the methodology's possible implementation at ORNL as part of the laboratory's knowledge management initiative. Use of the methodology during a voluntary or involuntary separation program does not provide enough time for knowledge transfer, but this methodology could be applied on an ongoing basis to improve knowledge management for experts. 


\section{BIBLIOGRAPHY}

International Atomic Energy Agency. (2006). Risk Management of Knowledge Loss in Nuclear Industry Organizations. Report no. IAEA-1248. Vienna, Austria.

International Atomic Energy Agency. (2011). Comparative Analysis of Methods and Tools for Nuclear Knowledge Preservation and Management. Nuclear Energy Series. Vienna, Austria.

Lucas, K. (2017). “What Are Some Questions for a Functional Technical Skills Interview?” Houston Chronicle. Retrieved March 28, 2017, from Houston Chronicle: http://work.chron.com/questionsfunctional-technical-skills-interview-28720.html

Ron Cain, Carla Agreda, and Bernadette Kirk. (August 2017). Supplement to a Methodology for Succession Planning for Technical Experts. Report no. ORNL/TM-2017/424, Oak Ridge National Laboratory, Oak Ridge, TN.

Ron Cain, Shaheen Dewji, Carla Agreda, and Bernadette Kirk. (July 2017). A Methodology for Succession Planning for Technical Experts. Report no. ORNL/TM-2017/74, Oak Ridge National Laboratory, Oak Ridge, TN. 


\section{APPENDIX A: TECHNICAL EXPERT INTERVIEW QUESTIONS}

These questions are derived from (IAEA, 2006) and (Lucas, 2017). They were modified for the purposes of this study.

\section{TACIT KNOWLEDGE}

1. What is your job title?

2. What educational background do you have?

3. How long have you been with the organization?

4. Do you have experience as an expert in previous jobs that relates to your current job?

5. What is your major function in your current job?

6. In your current role, what unique skill sets are required? In what areas do fellow employees seek your expertise?

7. Does your workplace have a process to capture vital knowledge?

8. What available organizational resources aid you in performing your job?

9. Does your work necessitate that you to keep up with publications (e.g., open literature)?

10. Other than the general organizational requirements, do you have to attend job-specific critical training on a regular basis? How often?

11. What other roles do you have?

12. If you had to leave the organization for any circumstance, how long do you think it would take for someone to adequately assume your role?

13. In relation to the above question, what would be the timeframe for training your replacement?

14. What are the top three things you would share with someone new to this role?

\section{EXPLICIT KNOWLEDGE}

1. Does a physical library exist for documented resources?

2. Are there databases available?

\section{PROFESSIONAL ACTIVITIES}

1. Are you a member of a professional society?

2. If so, how does the membership add value to your job? 